\title{
Infectious Hepatitis A Virus Particles Produced in Cell Culture Consist of Three Distinct Types with Different Buoyant Densities in $\mathrm{CsCl}$
}

\author{
STANLEY M. LEMON, ${ }^{1,2 *}$ ROBERT W. JANSEN, ${ }^{1}$ AND JOHN E. NEWBOLD ${ }^{2}$ \\ Division of Infectious Diseases, Department of Medicine ${ }^{1}$ and Department of Microbiology and Immunology, ${ }^{2}$ University \\ of North Carolina at Chapel Hill, Chapel Hill, North Carolina 27514
}

Received 2 November 1984/Accepted 20 December 1984

\begin{abstract}
Although hepatitis A virus (HAV) released by infected BS-C-1 cells banded predominantly at $1.325 \mathrm{~g} / \mathrm{cm}^{3}$ (major component) in $\mathrm{CsCl}$, smaller proportions of infectious virions banded at $1.42 \mathrm{~g} / \mathrm{cm}^{3}$ (dense $\mathrm{HAV}$ particles) and at $1.27 \mathrm{~g} / \mathrm{cm}^{3}$ (previously unrecognized light HAV particles). cDNA-RNA hybridization confirmed the banding of viral RNA at each density, and immune electron microscopy demonstrated apparently complete viral particles in each peak fraction. The ratio of the infectivity (radioimmunofocus assay) titer to the antigen (radioimmunoassay) titer of the major component was approximately 15-fold greater than that of dense HAV particles and 4-fold that of light HAV particles. After extraction with chloroform, the buoyant density of light and major component HAV particles remained unchanged, indicating that the lower density of the light particles was not due to association with lipids. Light particles also banded at a lower density $\left(1.21 \mathrm{~g} / \mathrm{cm}^{3}\right)$ in metrizamide than did the major component $\left(1.31 \mathrm{~g} / \mathrm{cm}^{3}\right)$. Dense $\mathrm{HAV}$ particles, detected by subsequent centrifugation in $\mathrm{CsCl}$, were indistinguishable from the major component when first banded in metrizamide $\left(1.31 \mathrm{~g} / \mathrm{cm}^{3}\right)$. However, dense $\mathrm{HAV}$ particles recovered from $\mathrm{CsCl}$ subsequently banded at 1.37 $\mathrm{g} / \mathrm{cm}^{3}$ in metrizamide. Electrophoresis of virion RNA under denaturing conditions demonstrated that dense, major-component, and light HAV particles all contained RNA of similar length. Thus, infectious HAV particles released by BS-C-1 cells in vitro consist of three distinct types which band at substantially different densities in $\mathrm{CsCl}$, suggesting different capsid structures with varied permeability to cesium or different degrees of hydration.
\end{abstract}

Although the morphology and structure of hepatitis A virus (HAV) closely resemble that of poliovirus, there are marked differences in the biological behavior of these two picornaviruses. Unlike poliovirus, HAV is uniformly noncytopathic in cell culture and replicates relatively slowly (1, $8,10,16)$. Even a virus which is well adapted to cell culture requires a number of days to reach maximum yields. Once established, however, infection has been persistent in all cell types examined and is without apparent effect on cellular macromolecular synthesis (25).

A striking feature of $\mathrm{HAV}$ is the wide range of buoyant densities which have been reported for this virus (reviewed by Coulepis et al. [7]). Feinstone et al. (9) initially reported that $\mathrm{HAV}$ recovered from human feces banded in $\mathrm{CsCl}$ at a density of $1.40 \mathrm{~g} / \mathrm{cm}^{3}$. Similar results were obtained by Locarnini et al. (13). However, a number of subsequent reports described the predominant banding of HAV particles or HAV antigenic activity from a variety of primate specimens at a density of 1.32 to $1.34 \mathrm{~g} / \mathrm{cm}^{3}$ in $\mathrm{CsCl}$ gradients (3, $4,17,20,21)$. Several of these studies, however, also confirmed the existence of a second, usually minor species of HAV virions banding at a density of 1.40 to $1.44 \mathrm{~g} / \mathrm{cm}^{3}(3$, $4,20,21)$. In addition, HAV particles banding at a density of 1.29 to $1.31 \mathrm{~g} / \mathrm{cm}^{3}$ have been described and appear to represent empty capsids $(20,21)$. Coulepis et al. (7) have summarized these findings by suggesting the existence of three different HAV particle types: a relatively light, empty capsid structure $\left(1.29\right.$ to $\left.1.31 \mathrm{~g} / \mathrm{cm}^{3}\right)$; an intact, normal virion (1.33 to $\left.1.34 \mathrm{~g} / \mathrm{cm}^{3}\right)$; and a minor virion species consisting of particles which are either more permeable to cesium ions or

\footnotetext{
* Corresponding author.
}

otherwise bind more cesium ions and thus have an increased density $\left(1.40\right.$ to $\left.1.45 \mathrm{~g} / \mathrm{cm}^{3}\right)$ when placed in cesium solutions.

Fewer data are available concerning the characteristics of HAV particles produced by infected cell cultures. Siegl et al. (22) found $\left[{ }^{3} \mathrm{H}\right]$ uridine to be incorporated into HAV particles with densities of $1.33 \mathrm{~g} / \mathrm{cm}^{3}$ (major component) and 1.39 to $1.44 \mathrm{~g} / \mathrm{cm}^{3}$ within infected human hepatoma cells. A minor antigen component banded at 1.30 to $1.32 \mathrm{~g} / \mathrm{cm}^{3}$ but did not incorporate $\left[{ }^{3} \mathrm{H}\right]$ uridine. In this report, we demonstrate the infectivity of both dense $\left(1.42-\mathrm{g} / \mathrm{cm}^{3}\right)$ and major-component $\left(1.325-\mathrm{g} / \mathrm{cm}^{3}\right)$ particle types and describe a third, previously unrecognized, infectious HAV virion which possesses a buoyant density in $\mathrm{CsCl}$ of approximately $1.27 \mathrm{~g} / \mathrm{cm}^{3}$ (light HAV particle).

\section{MATERIALS AND METHODS}

Cells. Virus was propagated in $490-\mathrm{cm}^{2}$ roller-bottle cultures of continuous green monkey kidney (BS-C-1) cells (passage 60 to 67), under conditions described previously (11). After inoculation with virus, cells were maintained in Eagle minimal essential medium supplemented with $2 \%$ heat-inactivated fetal bovine serum, glutamine $(100 \mathrm{mM})$, penicillin $(100 \mathrm{U} / \mathrm{ml})$, and streptomycin $(100 \mu \mathrm{g} / \mathrm{ml})$. Medium was replaced weekly.

Virus. HAV strain HM-175 had been adapted to growth in BS-C-1 cells as described previously $(1,11)$. Virus used in the experiments described in this paper had been passed 10 times in low-passage African green monkey kidney cells and 1 to 4 times in BS-C-1 cells.

Solid-phase radioimmunoassay for HAV. HAV was detected in cell culture supernatant fluids and gradient fractions by a solid-phase microtiter radioimmunoassay de- 
scribed previously (12). Quantitation of viral antigen in gradient fractions was based on the testing of twofold dilutions, the titer being determined by the highest dilution yielding a radioimmunoassay signal greater than or equal to 2.1 times that generated by culture medium alone.

Indirect plaque assay for HAV. Quantitation of infectious HAV was carried out by the radioimmunofocus method (11). This technique is similar to standard viral plaque assays except that foci of viral replication (radioimmunofoci) are detected by autoradiography after fixation of the cell sheet and staining with ${ }^{125}$ I-labeled anti-HAV. Results are reported in terms of radioimmunofocus-forming units of virus.

$\mathrm{CsCl}$ isopycnic centrifugation of $\mathrm{HAV}$. Supernatant fluids were harvested weekly from infected roller-bottle cultures of BS-C-1 cells and clarified by centrifugation at 7,000 $\times g$ for $30 \mathrm{~min}$. After the addition of $10 \%$ polyethylene glycol (PEG) 8000 and $2.3 \% \mathrm{NaCl}$, the medium was stirred gently overnight at $4^{\circ} \mathrm{C}$. Precipitated virus was collected by centrifugation at $10,000 \times g$ for $30 \mathrm{~min}$, suspended in distilled water, and mixed with a solution of $\mathrm{CsCl}$ to obtain a final density of $1.34 \mathrm{~g} / \mathrm{cm}^{3}$. In some cases (noted in text), PEG-precipitated virus was initially purified by sedimentation through a $30-\mathrm{ml}$ 10 to $30 \%$ (wt/wt) linear, rate-zonal sucrose gradient before isopycnic centrifugation. Rate-zonal gradients were centrifuged at $141,000 \times g$ for $130 \mathrm{~min}$ at $4^{\circ} \mathrm{C}$ in a Beckman SW27 rotor (Beckman Instruments, Inc., Palo Alto, Calif.). Isopycnic centrifugation was carried out in 5-ml gradients spun at $200,000 \times g$ for $22 \mathrm{~h}$ at $4^{\circ} \mathrm{C}$ in a Beckman SW40 rotor. Fractions (100 $\mu \mathrm{l}$ each) were collected from the bottom of each gradient, and 5 to $10-\mu$ l samples of each fraction were tested for HAV antigen by radioimmunoassay. Densities of fractions were estimated from the refractive index determined by an Abbe-type refractometer.

Isopycnic centrifugation of $\mathrm{HAV}$ in metrizamide. HAV samples were mixed with $4 \mathrm{ml}$ of a $50 \%$ (wt/vol) aqueous solution of metrizamide (Sigma Chemical Co., St. Louis, Mo.), layered onto a 1-ml cushion of $80 \%$ (wt/vol) metrizamide, and spun at $200,000 \times g$ for $72 \mathrm{~h}$ at $4^{\circ} \mathrm{C}$ in a Beckman SW40 rotor. Fractions were collected from the bottom of the tube and tested for HAV as described above. Densities of metrizamide gradient fractions were estimated from the refractive index.

Immune electron microscopy. Immune electron microscopy was carried out by S. M. Feinstone, National Institute of Allergy and Infectious Diseases, Bethesda, Md. Samples $(7 \mu \mathrm{l})$ of selected gradient fractions were mixed with $10 \mu \mathrm{l}$ of a 1:10 dilution of immune chimpanzee serum $(\mathrm{CH} 753)$ and 50 $\mu l$ of water. Samples were examined with a JEOL-100B electron microscope at 50,000 magnification.

Extraction of viral RNA. Total cellular RNA was obtained from trypsinized normal and HAV-infected BS-C-1 cells (21 days after infection) by the guanidinium isothiocyanate-cesium chloride technique (14), extracted with chloroformisoamyl alcohol (24:1), and precipitated with cold ethanol. For extraction of RNA from purified virions, virus-containing gradient fractions were diluted by the addition of $5 \mathrm{ml}$ of extraction buffer (20 mM Tris-hydrochloride [pH 7.4], 50 $\mathrm{mM} \mathrm{NaCl}, 1 \mathrm{mM}$ EDTA, $0.1 \% \beta$-mercaptoethanol, $0.01 \%$ Triton X-100), and virus particles were pelleted by centrifugation at $200,000 \times g$ for $6.5 \mathrm{~h}$. Virus was resuspended in 200 $\mu l$ of extraction buffer, and carrier RNA (10 $\mu \mathrm{g}$ of wheat germ rRNA) was added. Virions were disrupted by incubation for $5 \mathrm{~h}$ at $37^{\circ} \mathrm{C}$ in the presence of $0.5 \%$ sodium dodecyl sulfate, $0.5 \mathrm{mg}$ of proteinase $\mathrm{K}$ per $\mathrm{ml}$ (E. Merck AG, Darmstadt, Federal Republic of Germany), and $25 \mathrm{mM}$ EDTA, and virion RNA was extracted twice with phenol (previously equilibrated with $0.1 \mathrm{M} \mathrm{Na}$ acetate)-chloroform (1:1) and precipitated with cold ethanol. Precipitated RNA was washed three times with $70 \%$ ethanol and stored at $-20^{\circ} \mathrm{C}$.

HAV cDNA probes. Escherichia coli transformed with the recombinant pBR322 plasmid LB148, which contains an insert of cDNA complementary to a portion of wild-type (marmoset passage 6) HM-175 strain virion RNA, was the gift of J. R. Ticehurst, National Institute of Allergy and Infectious Diseases (24). Plasmid DNA was isolated after cell lysis by repetitive banding in $\mathrm{CsCl}$ with ethidium bromide. ${ }^{32} \mathrm{P}$-labeled cDNA probes were prepared from whole plasmid DNA by alkaline denaturation, followed by transcription with $E$. coli DNA polymerase I (Boehringer Mannheim Biochemicals, Indianapolis, Ind.) and random priming with calf thymus oligodeoxynucleotides in the presence of ${ }^{32}$ P]TTP (New England Nuclear Corp., Boston, Mass.) (23). A control pBR322 probe containing no HAV cDNA sequences was similarly prepared.

HAV cDNA-RNA hybridization. RNA solutions were blotted onto nitrocellulose paper (Schleicher \& Schuell, Inc., Keene, N.H.) with the Minifold II slot-blot apparatus (Schleicher \& Schuell). For direct blotting of $\mathrm{CsCl}$ gradient fractions, 5- to $50-\mu l$ samples were diluted into $500 \mu \mathrm{l}$ of $4.61 \mathrm{M}$ formaldehyde in $7.5 \times \mathrm{SSC}(1 \times \mathrm{SSC}$ is $0.15 \mathrm{M} \mathrm{NaCl}$ plus $0.015 \mathrm{M}$ sodium citrate) and applied directly to the nitrocellulose paper. The paper was dried at $23^{\circ} \mathrm{C}$ for $30 \mathrm{~min}$ and baked at $80^{\circ} \mathrm{C}$ for $2 \mathrm{~h}$ in a vacuum oven. Prehybridization was carried out for $3 \mathrm{~h}$ at $42^{\circ} \mathrm{C}$ with denatured calf thymus DNA $(100 \mu \mathrm{g} / \mathrm{ml})$ in prehybridization buffer $(50 \%$ formamide, $2.5 \times$ Denhardt solution, $5 \times \mathrm{SSC}, 0.1 \%$ sodium dodecyl sulfate). Labeled probes $\left(2 \times 10^{7}\right.$ to $\left.3 \times 10^{7} \mathrm{cpm}\right)$ were boiled for $3 \mathrm{~min}$ and added to $20 \mathrm{ml}$ of hybridization buffer (identical to prehybridization buffer except for $1 \times$ Denhardt solution) at $45^{\circ} \mathrm{C}$, and hybridization was carried out at $42^{\circ} \mathrm{C}$ for $20 \mathrm{~h}$ in sealed plastic bags. Nitrocellulose papers then were washed successively with $2 \times$ SSC with $0.1 \%$ sodium dodecyl sulfate at room temperature, followed by $0.1 \times \mathrm{SSC}$ with $0.1 \%$ sodium dodecyl sulfate at $52^{\circ} \mathrm{C}$, and exposed to XAR-5 film (Eastman Kodak Co., Rochester, N.Y.) overnight in X-Omat cassettes fitted with $\mathrm{X}$-Omatic intensifying screens (Eastman Kodak Co.).

The specificity of the HAV cDNA probe was confirmed in preliminary experiments with blotted whole cell RNA (from normal and infected BS-C-1 cells) and RNA from HAV virions purified from cell culture supernatant fluids by a combination of PEG precipitation, isopycnic centrifugation, and rate-zonal sedimentation. The HAV probe hybridized to purified virion RNA and showed evidence of specificity when tested against infected and uninfected BS-C-1 whole cell RNA (data not shown). The control pBR322 probe did not hybridize to either cellular RNA or purified virion RNA.

Formaldehyde-agarose gel electrophoresis of virion RNA. Extracted RNA samples were electrophoresed in 1\% agarose gels containing $2.2 \mathrm{M}$ formaldehyde using a Mini-gel apparatus (Hoefer Scientific Instruments, San Francisco, Calif.). Gels were soaked for $30 \mathrm{~min}$ in transfer buffer $(20 \times \mathrm{SSC}$ with $3 \%$ formaldehyde) and blotted against nitrocellulose paper overnight at room temperature (14). Papers were then dried, baked at $80^{\circ} \mathrm{C}$, and subjected to hybridization with the $\mathrm{HAV}$ cDNA probe as described above.

\section{RESULTS}

Buoyant density of HAV particles released by BS-C-1 cells. Virus, concentrated from clarified media by precipitation with PEG 8000, was banded isopycnically in $\mathrm{CsCl}$. HAV 
antigen was detected in gradient fractions by radioimmunoassay as three distinct peaks of activity banding at different densities (Fig. 1). Fractions comprising each of these three antigen peaks (indicated by arrows in Fig. 1) were separately pooled and subjected to a second round of isopycnic centrifugation under conditions similar to those used previously. Rebanding established the presence of three types of antigenic activities with distinctly different buoyant densities (Fig. 2). Dense, intermediate-density (major-component), and light activities rebanded at approximately $1.42,1.32$, and 1.27, respectively.

Because available tables relating refractive index to density of cesium chloride solutions are valid for solutions at $25^{\circ} \mathrm{C}$, virus was rebanded in $\mathrm{CsCl}$ at $25^{\circ} \mathrm{C}$, and the refractive index was determined at the same temperature to arrive at a more accurate estimate of virion buoyant density. ${ }^{3} \mathrm{H}$-labeled simian virus 40 (SV40) virions added as a standard density marker banded at a slightly higher density $(1.336$ $\mathrm{g} / \mathrm{cm}^{3}$ ) than did HAV under identical conditions $(1.325$ $\mathrm{g} / \mathrm{cm}^{3}$ ) (data not shown). All subsequent gradients described in this report were centrifuged at $4^{\circ} \mathrm{C}$, with the refractive index of individual fractions determined at $25^{\circ} \mathrm{C}$.

Infectivity of $\mathrm{HAV}$ antigenic activities with different buoyant densities. Selected peak fractions from each of the three gradients depicted in Fig. 2 were assayed for infectious virus by radioimmunofocus assay (11). Results (also shown in Fig. 2 ) indicated that each antigenic activity was associated with a peak of infectivity. These data thus indicate the release from infected cell cultures of three distinct, infectious HAV virion types with substantially different buoyant densities in $\mathrm{CsCl}$. Based on the titer of $\mathrm{HAV}$ present in each peak fraction, the major component contained approximately $99 \%$ of infectious virions released from BS-C-1 cells, whereas dense particles comprised $0.4 \%$ and light $\mathrm{HAV}$ particles comprised $0.6 \%$ of the total.

To obtain an estimate of the ratio of infectivity to antigen content for each particle type, the titer of HAV antigen in peak gradient fractions was determined by radioimmunoassay, and these results were related to infectivity as determined by the radioimmunofocus assay. The highest infectivity-antigen titer ratio was found with the major-component, intermediate-density particle type (Table 1). Based on anti-

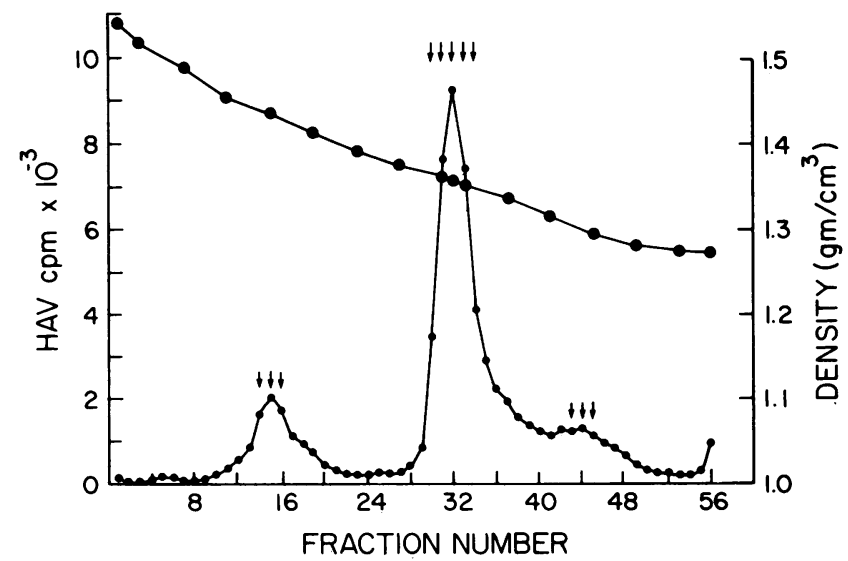

FIG. 1. HAV antigen detected by radioimmunoassay in fractions from a $\mathrm{CsCl}$ gradient containing $\mathrm{HAV}$ precipitated from cell culture supernatant fluids by the addition of PEG 8000 and $\mathrm{NaCl}$. The density shown is only an approximation because PEG may have interfered with refractive index determinations. Arrows indicate fractions pooled for rebanding in subsequent $\mathrm{CsCl}$ gradient (Fig. 2).

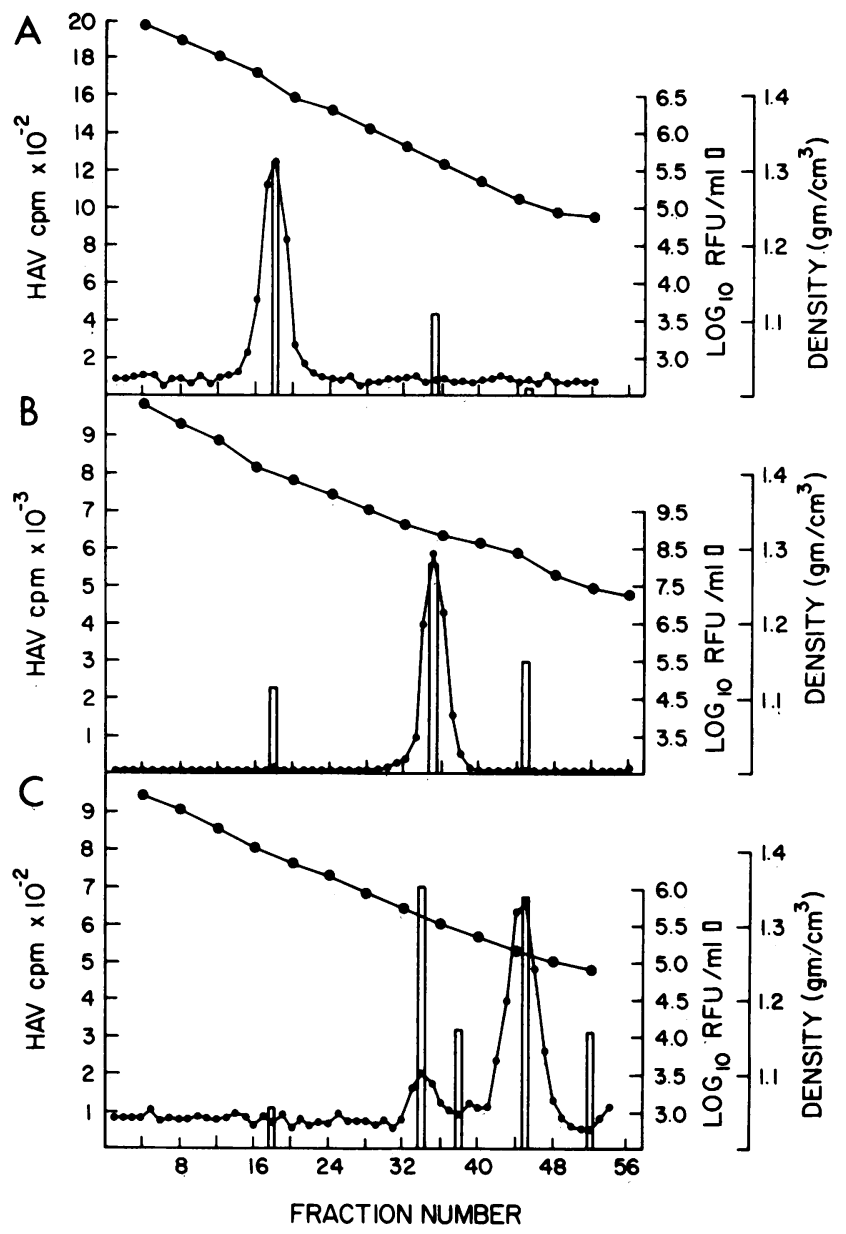

FIG. 2. Rebanding of HAV particle types from the gradient shown in Fig. 1. (A) Dense particles, rebanding of fractions 14 to 16 from the gradient shown in Fig. 1; (B) major component, rebanding of fractions 30 to 34 ; (C) light particles, rebanding of fractions 43 to 45. Results of radioimmunoassay testing for HAV antigen in each gradient fraction are shown, as are radioimmunofocus assay infectivity titrations (columns) of selected gradient fractions.

gen content, the major component had approximately 15fold greater specific infectivity than did dense HAV particles and 4-fold that of light HAV particles.

Immune electron microscopy of $\mathrm{HAV}$ particles. Immune electron microscopy (kindly performed by S. M. Feinstone) of fractions containing major-component and light HAV particles revealed numerous aggregates of particles with a diameter of approximately $27 \mathrm{~nm}$ (data not shown). Substantially fewer particles and only occasional aggregates were noted in the fraction containing dense HAV particles $(1.42$

TABLE 1. Infectivity of HAV virion types separated on the basis of buoyant density in $\mathrm{CsCl}$

\begin{tabular}{lllc}
\hline $\begin{array}{c}\text { Density } \\
(\mathrm{g} / \mathrm{ml})\end{array}$ & $\begin{array}{c}\text { Infectivity } \\
\left(\mathrm{RFU}^{a} / \mathrm{ml}\right)\end{array}$ & $\begin{array}{c}\text { Antigen } \\
\text { titer } \\
(\text { reciprocal })\end{array}$ & $\begin{array}{c}\text { Infectivity/ } \\
\text { antigen } \\
\text { ratio }\end{array}$ \\
\hline 1.27 & $7.2 \times 10^{5}$ & $4.0 \times 10$ & $1.8 \times 10^{4}$ \\
1.325 & $1.2 \times 10^{8}$ & $1.3 \times 10^{3}$ & $9.1 \times 10^{4}$ \\
1.42 & $4.8 \times 10^{5}$ & $8.0 \times 10$ & $6.0 \times 10^{3}$ \\
\hline
\end{tabular}

${ }^{a}$ RFU, Radioimmunofocus-forming units. 


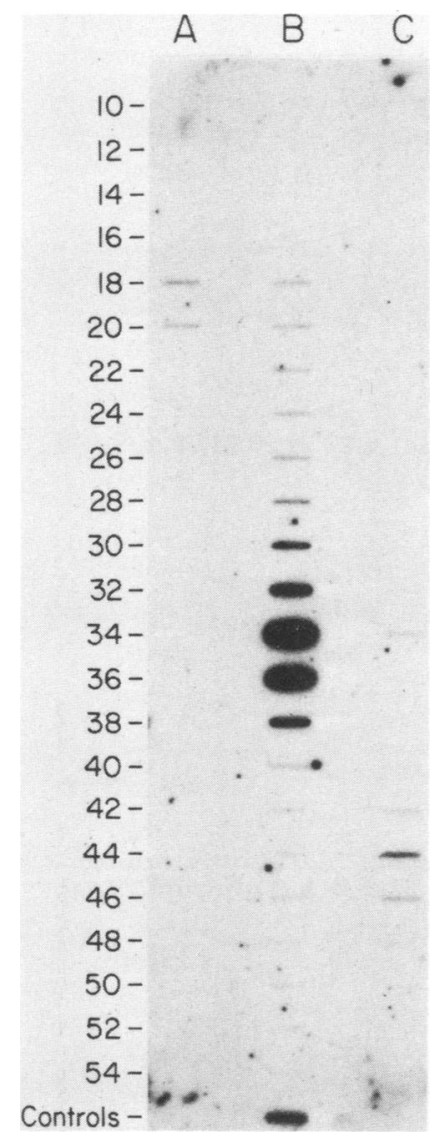

FIG. 3. cDNA-RNA slot-blot hybridizations of fractions from the three $\mathrm{CsCl}$ gradients shown in Fig. 2. Numbers to the left represent fraction numbers, collected from the bottom of the gradient. Lane A contains fractions from Fig. 2A (dense particles), lane B contains fractions from Fig. 2B (major component), and lane $\mathrm{C}$ contains fractions from Fig. 2C (light particles). Control RNA in lane $A$ is uninfected whole cell RNA, control in lane B is HAV-infected BS-C-1 whole cell RNA, and control in lane C is empty.

$\left.\mathrm{g} / \mathrm{cm}^{3}\right)$. The majority of particles present in each fraction appeared to be complete particles. A small number $(<3 \%)$ of particles present in the light-particle preparation appeared to be empty, and at least one such particle was noted in the fraction containing intermediate-density virions as well.

HAV RNA content of $\mathrm{CsCl}$ gradient fractions. To confirm the radioimmunoassay and infectivity results, HAV RNA was sought in fractions from the $\mathrm{CsCl}$ gradients depicted in Fig. 2 by slot-blot hybridization with cloned HAV cDNA as probe (Fig. 3). This probe was prepared from bacterial clones kindly provided by J. R. Ticehurst (24). Preliminary testing indicated that maximum sensitivity was achieved in the slot-blot system by the direct application of gradient fractions diluted in $4.61 \mathrm{M}$ formaldehyde-7.5× SSC to the nitrocellulose paper (see above). In each of the three gradients examined, the presence of HAV RNA correlated well with radioimmunoassay and infectivity results (Fig. 3). Overall, the results of cDNA hybridization confirmed the presence of HAV RNA-containing particles with buoyant densities of approximately $1.42,1.32$, and $1.27 \mathrm{~g} / \mathrm{cm}^{3}$.

Chloroform extraction of HAV particle types. A substantial fraction (up to $30 \%$ ) of $\mathrm{HAV}$ released into cell culture supernatant fluids resists neutralization with specific anti- body but can be rendered neutralizable by extraction with chloroform. This, plus the fact that nonneutralizable virus sediments less rapidly in sucrose (S. M. Lemon, L. N. Binn, manuscript in preparation), suggests that some HAV virions released by cell cultures might be associated with lipids. Therefore, to determine whether the light particles (1.27 $\mathrm{g} / \mathrm{cm}^{3}$ ) might represent lipid-associated virus, fractions comprising dense, major-component-, and light-particle peaks in the three gradients depicted in Fig. 2 were extracted once with an equal volume of chloroform. Extracted virus was rebanded isopycnically in $\mathrm{CsCl}$, and gradient fractions were assayed for antigen by radioimmunoassay (data not shown) and for HAV RNA by slot-blot hybridization (Fig. 4). Chloroform extraction of fractions containing the major component resulted in the rebanding of both HAV antigenic activity and HAV RNA at a density of approximately 1.32 $\mathrm{g} / \mathrm{cm}^{3}$. However, some HAV RNA also was detected at a density of $1.27 \mathrm{~g} / \mathrm{cm}^{3}$. After chloroform extraction of the light particle, viral RNA again was detected at a density of $1.27 \mathrm{~g} / \mathrm{cm}^{3}$, although viral antigen, present at the same density, was nearly undetectable by radioimmunoassay. Neither antigen nor RNA was detected at $1.32 \mathrm{~g} / \mathrm{cm}^{3}$ in this gradient. Thus, the banding of light particles at $1.27 \mathrm{~g} / \mathrm{cm}^{3}$

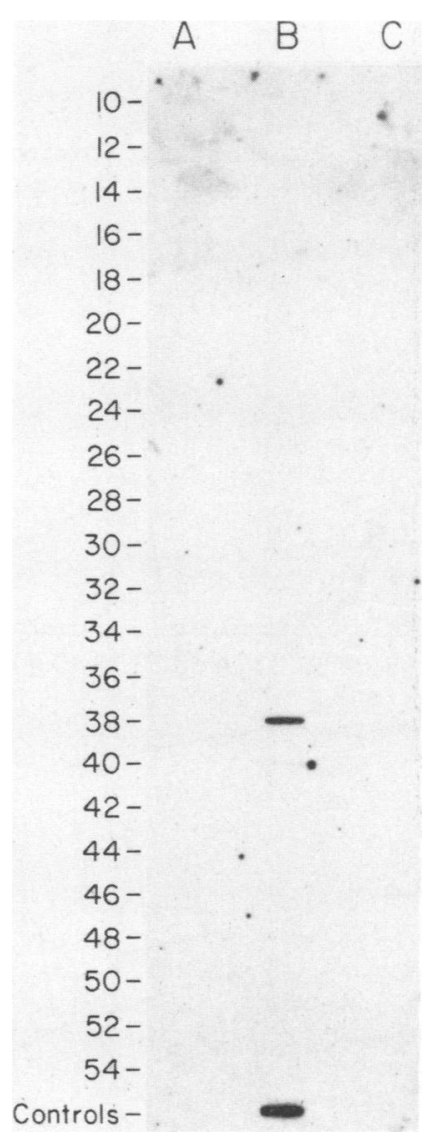

FIG. 4. cDNA-RNA slot-blot hybridizations of fractions from $\mathrm{CsCl}$ gradients containing chloroform-extracted peak fractions from the gradients shown in Fig. 2. Lane A contains chloroform-extracted dense particles, lane B contains chloroform-extracted major component particles, and lane $\mathrm{C}$ contains chloroform-extracted light particles. In lane B, fraction 38 had a density of $1.31 \mathrm{~g} / \mathrm{cm}^{3}$ and fraction 48 had a density of $1.27 \mathrm{~g} / \mathrm{cm}^{3}$. In lane $C$, fraction 46 had a density of $1.27 \mathrm{~g} / \mathrm{cm}^{3}$. Controls are as described in the legend to Fig. 3 . 
could not be related to association of normal virions with lipids. Neither HAV antigen nor HAV RNA could be detected after chloroform extraction of dense HAV particles, suggesting that the dense particle might be relatively unstable $(2,4)$.

Isopycnic banding of HAV virions in metrizamide. Dense particles of poliovirus (density, 1.40 to $1.44 \mathrm{~g} / \mathrm{cm}^{3}$ ) have been related to increased virion permeability to cesium ions, with binding of cesium to virion RNA (see below). Therefore, to examine the banding characteristics of HAV in a nonionic density medium, virus was subjected to isopycnic banding in metrizamide after precipitation from culture medium with PEG and partial purification by rate-zonal sedimentation in sucrose. In metrizamide, virus predominantly banded at approximately $1.31 \mathrm{~g} / \mathrm{cm}^{3}$ with a lesser band at about 1.22
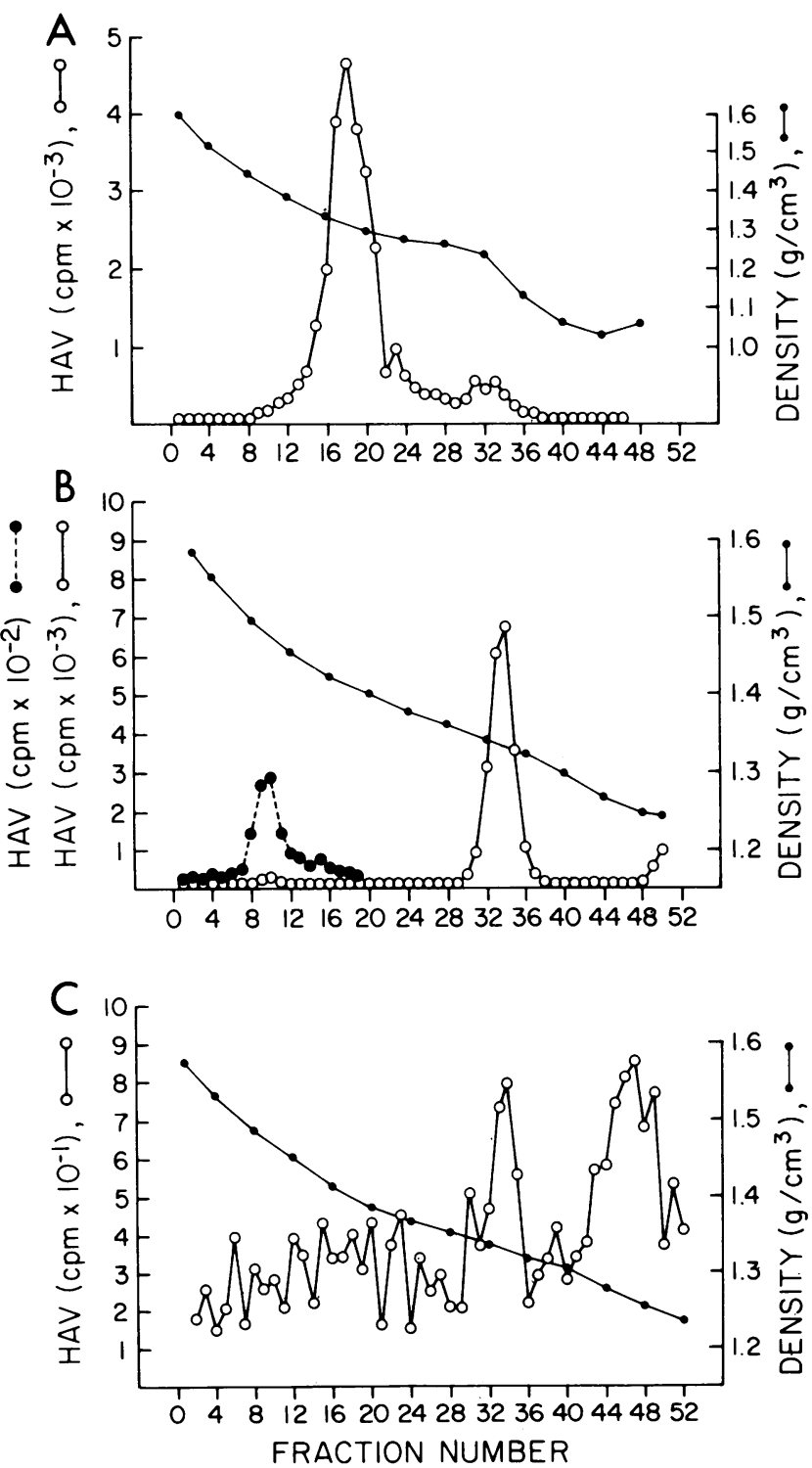

FIG. 5. Isopycnic banding of HAV in self-forming metrizamide gradients. Virus, partially purified by sedimentation through a rate-zonal sucrose gradient, was banded isopycnically in metrizamide (A). Fractions from the major (fractions 17 to 19) and minor (fractions 31 to 33 ) HAV peaks were separately pooled and rebanded in metrizamide (B and $\mathrm{C}$, respectively).
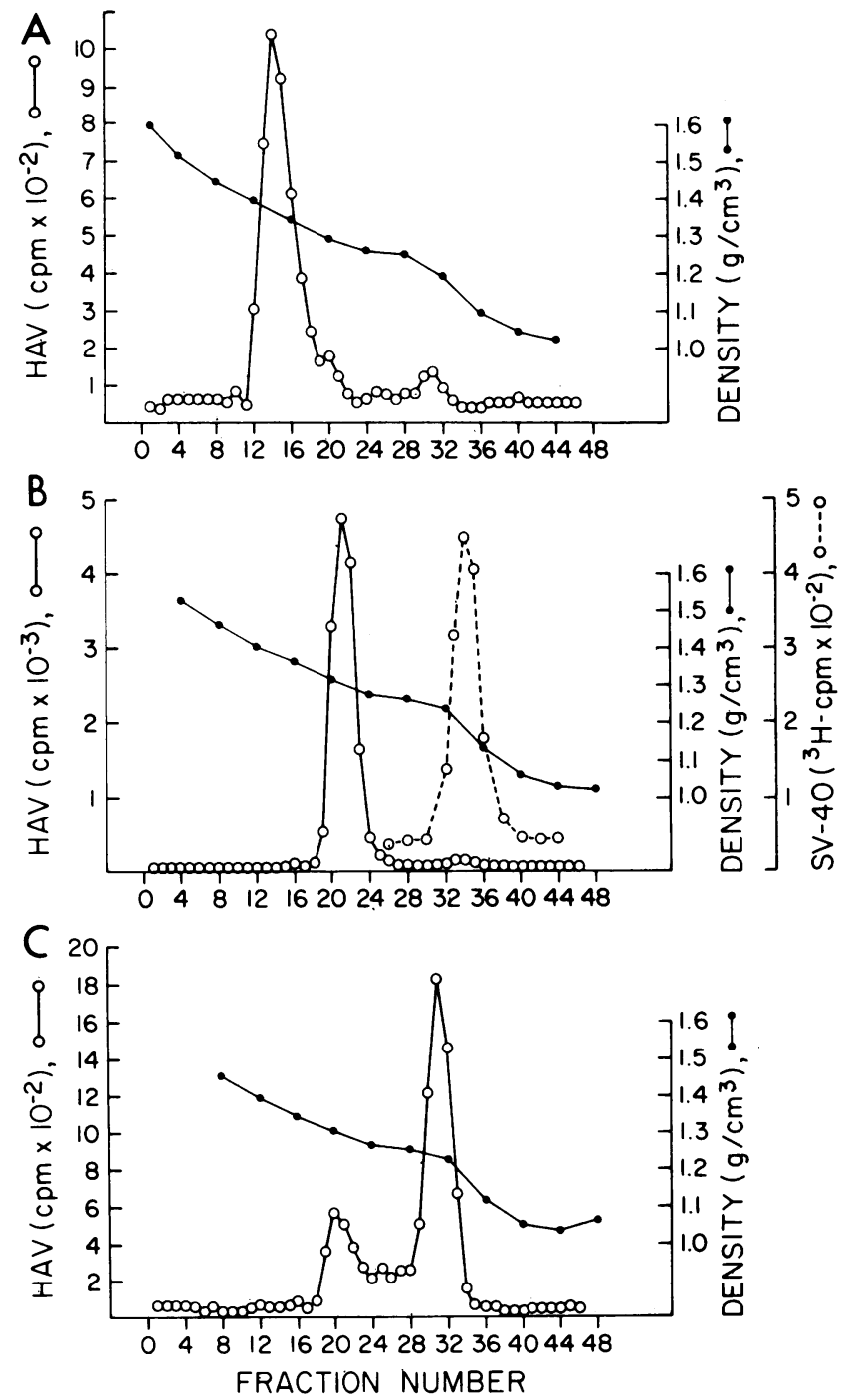

FIG. 6. Isopycnic banding in metrizamide of dense (A), intermediate-density (B), and light (C) HAV particle types recovered from $\mathrm{CsCl}$ gradients. The buoyant density of ${ }^{3} \mathrm{H}$-labeled SV40 in metrizamide also is shown (B).

$\mathrm{g} / \mathrm{cm}^{3}$ (Fig. 5A). Virus in the predominant peak of this gradient was rebanded in $\mathrm{CsCl}$. In $\mathrm{CsCl}$, this virus resolved into two bands representing major-component, intermediatedensity particles and a lesser band of dense particles (Fig. 5B). Similar banding profiles were obtained in $\mathrm{CsCl}$ whether virus was taken from the central portion or the denser leading edge (fraction number, 14 to 16) of the major peak in metrizamide (Fig. 5A) (data not shown). Fractions comprising the lighter peak in this metrizamide gradient (number, 31 to 33) also were rebanded in $\mathrm{CsCl}$. This virus resolved into two peaks, representing major-component and light HAV particles (Fig. 5C). These virus peaks were at the limit of detection by radioimmunoassay but were clearly demonstrated by cDNA slot-blotting of individual gradient fractions (data not shown). Thus these data demonstrate that dense and intermediate-density HAV particle types have identical buoyant densities in metrizamide but resolve when placed in cesium chloride solution, a finding consistent with the explanation proposed for other picornavirus dense par- 
TABLE 2. Buoyant densities of HAV particle types

\begin{tabular}{lll}
\hline \multirow{2}{*}{ Particle type } & \multicolumn{2}{c}{ Buoyant density $\left(\mathrm{g} / \mathrm{cm}^{3}\right)$ in: } \\
\cline { 2 - 3 } & $\mathrm{CsCl}$ & Metrizamide \\
\hline Dense & 1.42 & $1.31(1.37)^{a}$ \\
Major component & 1.325 & 1.31 \\
Light & 1.27 & 1.21 \\
\hline
\end{tabular}

${ }^{a}$ After recovery of dense particles from $\mathrm{CsCl}$.

ticles $(15,26)$. In contrast, light HAV particles were clearly less dense than the major component when banded in metrizamide, indicating that their presence was not an artifact related to the nature of the density gradient medium. In fact, virus examined in this series of gradients seems to have been partially depleted of light particles during the rate-zonal sedimentation in sucrose which preceded the metrizamide gradient.

The banding characteristics of HAV virion types in metrizamide were also examined after initial isopycnic banding in $\mathrm{CsCl}$. In this experiment, PEG-precipitated virus was first banded in $\mathrm{CsCl}$. Fractions containing dense, major-component, and light HAV particles were pooled, extracted with an equal volume of chloroform, and rebanded in $\mathrm{CsCl}$ (data not shown). Distinct peaks representing each particle type were obtained, indicating again that light particles were not sensitive to chloroform. Fractions containing dense, majorcomponent, and light HAV particles from this gradient then were separately pooled and rebanded in self-forming metrizamide gradients (Fig. 6). Dense HAV particles isolated from $\mathrm{CsCl}$ banded at a higher density (approximately 1.37 $\mathrm{g} / \mathrm{cm}^{3}$ ) than did major-component particles (Fig. 6A and B). Thus, although dense and major-component particles had identical buoyant densities in metrizamide before being placed in cesium chloride solution (Fig. 5), these HAV particle types banded at different densities in metrizamide after removal from $\mathrm{CsCl}$. These observations strongly support the hypothesis that dense HAV particles isolated from cell culture are relatively dense due to binding of cesium cations. Light $\mathrm{HAV}$ particles isolated from $\mathrm{CsCl}$ banded in metrizamide at a lighter density (about $1.23 \mathrm{~g} / \mathrm{cm}^{3}$ ) than did major-component particles (Fig. 6C). The buoyant density of these particles in metrizamide was not affected by prior banding in $\mathrm{CsCl}$. Buoyant density data are summarized in Table 2.

The relative densities of $\mathrm{HAV}$ and SV40 virus were reversed in $\mathrm{CsCl}$ and metrizamide, indicating that specific density gradient media may exert a strong but variable influence on the buoyant density of different viruses. Although SV40 was slightly denser than HAV in $\mathrm{CsCl}(1.336$ $\mathrm{g} / \mathrm{cm}^{3}$ for SV40 versus $1.325 \mathrm{~g} / \mathrm{cm}^{3}$ for HAV), it banded at a density significantly less than that of $\mathrm{HAV}$ in metrizamide $\left(1.20 \mathrm{~g} / \mathrm{cm}^{3}\right.$ for $S V 40$ versus $1.31 \mathrm{~g} / \mathrm{cm}^{3}$ for HAV), possibly reflecting different proportions of nucleic acid and protein in the composition of each virus.

Size of virion RNA in dense, major-component, and light HAV particles. Peak fractions from the gradients shown in Fig. 2 were pooled, and RNA was extracted from each as described above. After electrophoresis in formaldehydeagarose, RNA was blotted to nitrocellulose paper and hybridized to labeled HAV cDNA. A single band of HAV RNA was detected in peak fractions from the two gradients containing dense and light HAV particles (Fig. 7). In both cases, this RNA appeared to be similar in size to the RNA extracted from the major component particle, and of the same length as the longest HAV RNA species detectable in infected cell cultures. Based on comparison with Sma restriction fragments of adenovirus type 2 DNA run concurrently as size markers, the HAV RNA from all three virion types was estimated to be somewhat greater than 7,000 nucleotides in length. A small proportion of the RNA extracted from both the major-component and heavy particles consisted of molecules of less than genomic length and appeared as a faint smear below the prominent RNA band in the Northern blots. Although this subgenomic RNA could represent RNA from defective particles, it also may have resulted from degradation of the RNA after extraction.

\section{DISCUSSION}

Based on physical properties, including its polypeptide composition and positive-sense, 3 '-polyadenylated RNA genome, HAV has been classified as a picornavirus (7). In general, the buoyant density profile of $\mathrm{HAV}$ in $\mathrm{CsCl}$ is in keeping with that of other picornaviruses, among which considerable variation is found. Foot-and-mouth disease virus bands in $\mathrm{CsCl}$ at a predominant density of 1.42 to 1.44 $\mathrm{g} / \mathrm{cm}^{3}$, human rhinoviruses band at about 1.38 to $1.42 \mathrm{~g} / \mathrm{cm}^{3}$, and human enteroviruses, including poliovirus, band at about $1.34 \mathrm{~g} / \mathrm{cm}^{3}$ (19). However, a small proportion of poliovirus and some other enteroviruses has been shown to band isopycnically at 1.40 to $1.44 \mathrm{~g} / \mathrm{cm}^{3}$ in $\mathrm{CsCl}(15,18,26)$. In addition, defective-interfering particles of poliovirus, which lack sequences near the $5^{\prime}$ end of the RNA genome, band isopycnically at 1.31 to $1.32 \mathrm{~g} / \mathrm{cm}^{3}(6)$, and empty poliovirus capsids band at about 1.29 to $1.30 \mathrm{~g} / \mathrm{cm}^{3}$ (19). We found the buoyant density of the major component of HAV to be $1.325 \mathrm{~g} / \mathrm{cm}^{3}$ in $\mathrm{CsCl}$. Although this is significantly less than the $1.34 \mathrm{~g} / \mathrm{cm}^{3}$ previously reported in studies of HAV derived from feces (reviewed in reference 7), Siegl et al. (22) also found cell culture-adapted HAV to be less dense than poliovirus $\left(1.33 \mathrm{~g} / \mathrm{cm}^{3}\right)$. The lower values for the buoyant density of HAV may reflect more precise measurement or perhaps a lower density for cell culture-adapted virus relative to wild-type HAV.

Dense $\left(1.40\right.$ to $\left.1.44 \mathrm{~g} / \mathrm{cm}^{3}\right)$ poliovirus particles have been explained on the basis of a more open capsid structure with increased capsid permeability to cesium ions $(15,26)$. Cesium presumably displaces cations with less mass which normally neutralize the negatively charged phosphate groups

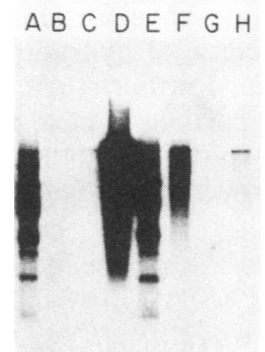

FIG. 7. Northern blot analysis of RNA extracted from isolated HAV virion types. Lanes A through $G$ represent 13-h exposures: A and E, adenovirus DNA size markers; B, is RNA from fractions 15 to 20 of the gradient shown at the top of Fig. 2 (dense particles); C, RNA from fractions 42 to 48 of the gradient shown at the bottom of Fig. 2 (light particles); D, RNA from fractions 34 to 36 of the middle gradient in Fig. 2 (major component); F, whole cell RNA extracted from infected BS-C-1 cells; G, whole cell RNA from uninfected cells. Lane $H$ represents a brief (15-min) exposure of lane D RNA from major-component particles. 
on the virion RNA, thus resulting in denser virions. Most poliovirions are impermeable to cesium ions, however, and do not alter their densities when placed in $\mathrm{CsCl}$ solutions (15). The dense particle, having a looser and more open capsid structure, also is less stable and more sensitive to RNase digestion when compared with normal poliovirus particles (26). A similar explanation is likely for dense HAV particles $(2,7)$. We found the buoyant density of dense HAV particles in a nonionic density gradient medium (metrizamide) was significantly altered after banding of the particles in $\mathrm{CsCl}$ (Fig. 5 and 6), whereas this was not the case with the major-component or light HAV particles. These observations confirm that dense HAV particles derive their increased density by binding cesium cations and suggest a common origin for $\mathrm{HAV}$ and poliovirus dense particles. However, compared with dense poliovirus particles which have been reported to be 5,000 -fold less infectious than normal poliovirus (26), our data suggest that dense HAV particles have a specific infectivity much closer to that of the major component (Table 1 ). In this regard, HAV may be more similar to swine vesicular disease virus in that dense particles of swine vesicular disease virus $\left(1.44 \mathrm{~g} / \mathrm{cm}^{3}\right)$ have a specific activity only fourfold less than that of the predominant swine vesicular disease virus particle type $\left(1.34 \mathrm{~g} / \mathrm{cm}^{3}\right)$ (18).

The light (approximately $1.27 \mathrm{~g} / \mathrm{cm}^{3}$ ) infectious HAV particle has not been observed previously and is considerably more difficult to explain. To our knowledge, this type of infectious particle has not been found in studies of poliovirus, although a lighter than normal but infectious coxsackie B5 particle $\left(1.30 \mathrm{~g} / \mathrm{cm}^{3}\right)$ has been recently described $(5)$. Unlike the light HAV particle, however, these atypical coxsackie B5 particles were membrane bound and significantly less infectious than normal virions.

Light HAV particles contain encapsidated RNA of approximately unit length (Fig. 7) but are less dense than even the empty capsid is thought to be $(20,21)$. The light particle appears to be fully infectious and does not have properties of poliovirus defective-interfering particles (6). It does not appear to be lighter than the major virion component because of association with lipids, as its density is not affected by vigorous extraction with chloroform (Fig. 4). On the contrary, the population of light particles appeared enriched after extraction of major-component particles with chloroform. Although light HAV particles are morphologically indistinguishable from the major component, it remains most likely that these virions have an altered capsid structure permitting a higher degree of hydration but not influencing permeability to cesium. Further studies of the capsid structure of these HAV particle types will be necessary to determine the veracity of this hypothesis but will be difficult due to the relatively low yield of light and dense particles in infected cell cultures.

\section{ACKNOWLEDGMENTS}

We are indebted to J. R. Ticehurst, National Institute of Allergy and Infectious Diseases, Bethesda, Md., for the gift of bacterial clones containing HAV cDNA recombinant plasmids and to $S$. $M$. Feinstone, also of the National Institute of Allergy and Infectious Diseases, for immune electron microscopy of gradient fractions.

\section{LITERATURE CITED}

1. Binn, L. N., S. M. Lemon, R. H. Marchwicki, R. R. Redfield, N. L. Gates, and W. H. Bancroft. 1984. Primary isolation and serial passage of hepatitis A virus strains in primate cell cultures. J. Clin. Microbiol. 20:28-33.
2. Bradley, D. W., H. A. Fields, K. A. McCaustland, E. H. Cook, C. R. Gravelle, and J. E. Maynard. 1978. Biochemical and biophysical characterization of light and heavy density hepatitis A virus particles. Evidence that HAV is an RNA virus. J. Med. Virol. 2:175-187.

3. Bradley, D. W., C. L. Hornbeck, C. R. Gravelle, E. H. Cook, and J. E. Maynard. 1975. CsCl banding of hepatitis A-associated virus-like particles. J. Infect. Dis. 131:304-305.

4. Bradley, D. W., K. A. McCaustland, M. T. Schreeder, E. H. Cook, C. R. Gravelle, and J. E. Maynard. 1977. Multiple buoyant densities of hepatitis A virus in cesium chloride gradients. J. Med. Virol. 1:219-226.

5. Chattergee, N. K., W. A. Samsonoff, and C. Tuchowski. 1983. Isolation and characterization of a membrane-bound population of group B coxsackieviruses. J. Virol. 45:832-841.

6. Cole, C. N. 1975. Defective interfering (DI) particles of poliovirus. Prog. Med. Virol. 20:180-207.

7. Coulepis, A. G., S. A. Locarnini, E. G. Westaway, G. A. Tannock, and I. D. Gust. 1982. Biophysical and biochemical characterization of hepatitis A virus. Intervirology 18:107-127.

8. Daemer, R. J., S. M. Feinstone, I. D. Gust, and R. H. Purcell. 1981. Propagation of human hepatitis A virus in African green monkey kidney cell culture: primary isolation and serial passage. Infect. Immun. 32:388-393.

9. Feinstone, S. M., A. Z. Kapikian, J. L. Gerin, and R. H. Purcell. 1974. Buoyant density of hepatitis A virus-like particle in cesium chloride. J. Virol. 13:1412-1414.

10. Frosner, G. G., F. Deinhardt, R. Scheid, V. Gauss-Muller, N. Holmes, V. Messelberger, G. Siegl, and J. J. Alexander. 1979. Propagation of human hepatitis A virus in a hepatoma cell line. Infection 7:303-305.

11. Lemon, S. M., L. N. Binn, and R. H. Marchwicki. 1983. Radioimmunofocus assay for quantitation of hepatitis A virus in cell cultures. J. Clin. Microbiol. 17:834-839.

12. Lemon, S. M., J. W. LeDuc, L. N. Binn, A. Escajadillo, and K. G. Ishak. 1982. Transmission of hepatitis A virus among recently captured Panamanian owl monkeys. J. Med. Virol. 10:25-36.

13. Locarnini, S. A., A. A. Ferris, A. C. Stott, and I. D. Gust. 1974. The relationship between a $27 \mathrm{~nm}$ virus-like particle and hepatitis $A$ as demonstrated by immune electron microscopy. Intervirology 4:110-118.

14. Maniatis, T., E. F. Fritsch, and J. Sambrook. 1982. Molecular cloning. A laboratory manual. Cold Spring Harbor Laboratory, Cold Spring Harbor, N.Y.

15. Mapoles, J. E., J. W. Anderegg, and R. R. Rueckert. 1978. Properties of poliovirus propagated in medium containing cesium chloride: implications for picornaviral structure. Virology 90:103-111.

16. Provost, P. J., and M. R. Hilleman. 1979. Propagation of human hepatitis A virus in cell culture in vitro. Proc. Soc. Exp. Biol. Med. 160:213-221.

17. Provost, P. J., B. S. Wolanski, W. J. Miller, O. L. Ittensohn, W. J. McAleer, and M. R. Hilleman. 1975. Physical, chemical and morphologic dimensions of human hepatitis A virus strain CR326. Proc. Soc. Exp. Biol. Med. 148:532-539.

18. Rowlands, D. J., M. W. Shirley, D. V. Sangar, and F. Brown. 1975. A high density component in several vertebrate enteroviruses. J. Gen. Virol. 29:223-234.

19. Rueckert, R. R. 1971. On the structure and morphogenesis of picornaviruses, p. 131-213. In $\mathbf{H}$. Fraenkel-Conrat and $\mathbf{R}$. Wagner (ed.), Comprehensive virology, vol. 6. Plenum Publishing Corp., New York.

20. A. N. Schulman, J. L. Dienstag, D. R. Jackson, J. H. Hoofnagle, R. H. Gerety, R. H. Purcell, and L. F. Barker. 1975. Hepatitis A particles in liver, bile and stool of chimpanzees. J. Infect. Dis. 134:80-84.

21. Siegl, G., and G. G. Frösner. 1978. Characterization and classification of virus particles associated with hepatitis A. I. Size, density, and sedimentation. J. Virol. 26:40-47.

22. Siegl, G., G. G. Frosner, V. Gauss-Muller, J. D. Tratschin, and F. Deinhardt. 1981. The physicochemical properties of infectious hepatitis A virions. J. Gen. Virol. 57:331-341. 
23. Summers, J. 1975. Physical map of polyoma viral DNA fragments produced by cleavage with a restriction enzyme from Haemophilus aegyptius, endonuclease R.HaeIII. J. Virol. 15:946-953.

24. Ticehurst, J. R., V. R. Racaniello, B. M. Baroudy, D. Baltimore, R. H. Purcell, and S. M. Feinstone. 1983. Molecular cloning and characterization of hepatitis A virus cDNA. Proc. Natl. Acad.
Sci. U.S.A. 80:5885-5889.

25. Vallbracht, A., L. Hoffmann, K. G. Wurster, and B. Flehmig. 1984. Persistent infection of human fibroblasts by hepatitis $A$ virus. J. Gen. Virol. 65:609-615.

26. Yamaguchi-Koll, U., K. J. Wiegers, and R. Drzeniek. 1975. Isolation and characterization of 'dense particles' from poliovirus-infected HeLa cells. J. Gen. Virol. 26:307-319. 